\title{
Role of exfoliative cytology in oral lesions: with special reference to rule out malignancy
}

\author{
A. Singh \\ Lecturer, Department of Pathology, College of Medical Sciences, Bharatpur, Nepal
}

\begin{abstract}
Oral malignancy is quite common in country like India because of tobacco chewing and smoking. Cytology is cheaper and easy procedure that can be carried out at outdoor patient department to diagnose malignancy at early stage. The present study carried out to detect cancer pre-invasive stage by use of exfoliative cytology and to explore the possibility of using this technique in diagnosis of other oral lesions considered as premalignant ones. A total 102 patients referred from OPD and surgery department of J.A. Group of Hospital, Madhav Dispensary and Cancer Hospital, Gwalior, between July 2004 to October 2005, were included in this study. Two smears by scrap method, from each patient were prepared and after air dried stained with RAPID PAP stain. The smear were evaluated along with clinical, epidemiological data and classified in group I to IV according to the Papanicolaou classification.

In our result 25 cases were normal. 47 were Leukoplakia with mean age 47.5 years, $85 \%$ male. Smear show anucleated squames predominantly $53 \%$. Six cases were submucous fibrosis $66.7 \%$ female with mean age 38.3 years and, smear revealed rarification of nuclei in $66 \%$ cases. Two cases of mucosal hyperemia (Erythema), one-one case of traumatic ulcer and granular buccal mucosa included. Out of Twenty cases of malignancy, male were $75 \%$ with mean age of 46 year. Cheek and tongue were the common site with incidence of $60 \%$. The smear revealed inflammatory cells in $100 \%$, malignant cells in $75 \%$ cases either in groups or in singles. The third type of cells $60 \%$, the undifferentiated cells $37 \%$, and Tadpole cells in 5\% cases. In study $75 \%$ cases were positive for cancer, $10 \%$ were suspicious for cancer and remaining $15 \%$ were given as negative for cancer.

Cytology is reliable diagnostic tool in diagnosis of presence or absence of malignancy in a lesion with high accuracy rate. The oral cytologic technique is easy to do and can provide the help of surgeon/physician, where he/she might hesitate to perform an invasive procedure, like a biopsy, or desire more information regarding a lesion before referring the patient.
\end{abstract}

Key words : Cancer, exfoliative cytology, leukoplakia, oral malignancy.

\section{Introduction}

Oral cancer is one of the ten most common cancers in the world. Its high frequency in central and south

Correspondence: Dr. Arjun Singh

E-mail: dr_arjunpath@rediffmail.com
East Asian countries viz. India, Bangladesh, Sri Lanka, Thailand, Indonesia and Pakistan has been well documented. Each year about 5,74,000 new cases and 3,20,000 deaths occur worldwide. ${ }^{1}$ Oral cancer is a major problem in India and accounts for $50-70 \%$ 
of all cancers diagnosed as compared to 2 to 3 percent in UK and USA. ${ }^{1}$

Cytology has now been widely accepted as a tool in the early diagnosis of cancer and has taken its rightful place besides the other recognized branches of hospital diagnostic services.

To gain wide acceptance any laboratory method must meet three principle requirements, (a) it should be simple to perform, (b) it should offer minimal discomfort and inconvenience to the patient (c) it must be accurate in its results. The method of cytodiagnosis meets these three requirements very well and that is why it has gained popularity within such a short period of time since its introduction by George N. Papanicolaou. ${ }^{2}$

Clinical cytology, in the hands of well trained personnel now posseses a sensitivity of 92 to $100 \%$ while its specificity has risen to somewhere between 97 to $100 \%$ (Nils G. Stromby,1999). ${ }^{3}$

Majority of the carcinomas of the oral cavity are of well differentiated squamous cell type. In these type of cases the malignant cells have a characteristic cytologic appearance and are usually quite easily recognized. ${ }^{4}$ This itself is a guarantee that cytodiagnosis is likely to yield a high degree of accuracy in cases of oral malignancies, cytologic recognition of premalignant lesion in various areas of the human body is still in its infancy. From the results achieved by workers like Sandler it seems there is great promise in its use in oral premalignant and in-situ carcinomas. 5,6,7,8

Cancers of the mouth as in other regions of the body freely exfoliate and, therefore, smears prepared from regions that harbor a cancer are usually rich in number with variety of exfoliated malignant cells. ${ }^{9}$
Silverman, Becks and Farber (1977) have suggested that cytologic technique, being simple and less injury-producing procedure, has the advantage of doing away with many undersirable features of a biopsy and that offers a simple yet reliable method of great predictability in cancer detection programme. ${ }^{10}$ It was with this view that the present work had been undertaken. This study has been taken up not only to find out whether cancer can be detected in its preinvasive stage by use of exfoliative cytology, but in addition an effort has been made to explore the possibility of using this technique in diagnosis of other oral lesions considered as premalignant ones.

\section{Materials and methods}

This study was carried out over a period, from July 2004 to October 2005. The material for the present study was collected from patients attending the out patient department of the J.A. Group of Hospitals including the E.N.T. and surgery department of Madhav dispensary as well as cancer research institute, Cancer Hill, Gwalior for various complaints pertaining to oral cavity. Informed expressed consent was obtained from all patients before including them in study. Approval from Ethical Committee was also taken out before starting study.

A detailed general examination of oral cavity was done in every case and positive findings along with a brief clinical history were noted down. Most of the cases required no prior preparation. In a few cases the lesions were found to be covered with debris or slough. Surfaces of such lesions were first cleaned by wiping with a piece of gauge moistened in normal saline solution and then the scraping was attempted. In some of the cases with highly keratinized lesion the 
A.Singh, Role of exfoliative cytology in oral lesions: with special reference to rule out malignancy

keratinized surface was removed by scraping it with a wooden spatula. In case of the lip lesions, the involved areas were first soaked with a piece of wet gauge for about 15 minutes before taking the scraped specimen.

Carefully labeled slide was held between the left thumb and the forefinger, the angle of the mouth was drawn laterally with the help of left little finger, a wooden tongue depressor which had previously been soaked in tap water was held in the right hand and with its help the entire surface of the lesion was scraped vigorously using the edge of the wet tongue depressor several times but mostly in one direction. Scrapings thus picked up on the edge of the tongue depressor were spread evenly and rapidly over the glass slide and the slide was immediately fixed with spray fixative given in Rapid PAP kit. Two smears were always prepared from each patient. The smears were allowed to dry in air. The smears prepared were stained by Rapid PAP kit in present study. The slides were mounted with cover glass using a drop of D.P.X. Mountant.

After screening cytologic smears were classified according to Papanicolaou's (1960) classification: ${ }^{2}$

Class I (Normal) - Only Normal cells were observed Class II (atypical) - Presence of minor atypia, but no evidence of malignancy.

Class III (Intermediate) - An in-between cytology. The cells display wide atypia that may be suggestive of malignancy, but they are not clear cut cancer and represent precancerous lesions or in situ carcinoma.

Class IV (Suggestive of cancer) - A few epithelial cells with malignant characteristics or cells with borderline characteristics.

Class V - Positive cancer cells, that are obviously malignant. $^{2}$

\section{Result}

Two hundred and four oral mucosal smear from 102 patients were collected, in which 25 were normal group. The normal group act as control in the study. The normal group comprises people without complaint pertaining to teeth and whose oral mucosa appeared absolutely normal on clinical examination. Cases with history of tobacco chewing and smoking were not included in this group of normal cases. (Table No.1)

In our study the maximum age incidence of Leukoplakia was 31-40 years observed in $61.7 \%$ cases with mean age of 47.5 . The $85 \%$ cases were male. In Leukoplakia $97.8 \%$ cases were either tobacco chewer or smokers and $12.7 \%$ patients came with complaint directly related to the leukoplakic patch while remaining were unaware with the problem. Most common site of involvement was mucosa of the cheek in $87.2 \%$ cases. (Table No.2)

No malignant cells were detected on any smear of Leukoplakia. Anucleated squames were present in 53\% cases. In Leukoplakia, mild degree acidophilia in $38 \%$ and moderate acidophilia in $36 \%$ cases was present. Karyorrhexis 25\%, prominent nuclear membrane $11 \%$, prominent nucleoli $6 \%$ and rarification of nuclei $4 \%$ cases were observed. (Table No.3)

Six cases of submucous fibrosis were included in study. $50 \%$ were age group of $31-40$ years (mean age 38.3 years) and $66.7 \%$ female. All cases were with complaint of restricted movement of lower jaw and inability to open mouth completely. No female patient gave history of tobacco or betel nut chewing.

Cytologically smear showed rarification of nuclei $66 \%$, irregular maturation of cytoplasm $50 \%$, and mild atypia in 50\% cases. No smear showed any evidence of malignancy. (Table No.4) 
Table 1

Age and Sex Distribution of Cases.

\begin{tabular}{|c|c|c|c|c|c|c|c|}
\hline $\begin{array}{l}\text { Age } \\
\text { group }\end{array}$ & Normal & Leukoplakia & $\begin{array}{l}\text { Submucous } \\
\text { fibrosis }\end{array}$ & $\begin{array}{l}\text { Mucosal } \\
\text { hyperemia }\end{array}$ & $\begin{array}{l}\text { Traumatic } \\
\text { Ulcer }\end{array}$ & $\begin{array}{l}\text { Granular } \\
\text { mucosa }\end{array}$ & Carcinoma \\
\hline $20-30$ & $\begin{array}{l}\mathrm{M}=2(8 \%) \\
\mathrm{F}=0 \\
\mathrm{~T}=2(8 \%)\end{array}$ & $\begin{array}{l}\mathrm{M}=3(6.38 \%) \\
\mathrm{F}=1(2.12 \%) \\
\mathrm{T}=4(8.5 \%)\end{array}$ & $\begin{array}{l}\mathrm{M}=0 \\
\mathrm{~F}=1(16.7 \%) \\
\mathrm{T}=1(16.7 \%)\end{array}$ & $\begin{array}{l}\mathrm{M}=0 \\
\mathrm{~F}=0 \\
\mathrm{~T}=0\end{array}$ & $\begin{array}{l}\mathrm{M}=0 \\
\mathrm{~F}=0 \\
\mathrm{~T}=0\end{array}$ & $\begin{array}{l}M=0 \\
F=0 \\
T=0\end{array}$ & $\begin{array}{l}M=0 \\
F=0 \\
T=0\end{array}$ \\
\hline $31-40$ & $\begin{array}{l}\mathrm{M}=1(4 \%) \\
\mathrm{F}=2(8 \%) \\
\mathrm{T}=3(12 \%)\end{array}$ & $\begin{array}{l}\mathrm{M}=10(21.2 \%) \\
\mathrm{F}=1(2.12 \%) \\
\mathrm{T}=11(23.4 \%)\end{array}$ & $\begin{array}{l}\mathrm{M}=1(16.7 \%) \\
\mathrm{F}=2(33.3 \%) \\
\mathrm{T}=3(50 \%)\end{array}$ & $\begin{array}{l}\mathrm{M}=0 \\
\mathrm{~F}=0 \\
\mathrm{~T}=0\end{array}$ & $\begin{array}{l}\mathrm{M}=0 \\
\mathrm{~F}=0 \\
\mathrm{~T}=0\end{array}$ & $\begin{array}{l}\mathrm{M}=1(100 \%) \\
\mathrm{F}=0 \\
\mathrm{~T}=1(100 \%)\end{array}$ & $\begin{array}{l}\mathrm{M}=3(15 \%) \\
\mathrm{F}=2(10 \%) \\
\mathrm{T}=5(25 \%)\end{array}$ \\
\hline $41-50$ & $\begin{array}{l}\mathrm{M}=6(24 \%) \\
\mathrm{F}=6(24 \%) \\
\mathrm{T}=12(48 \%)\end{array}$ & $\begin{array}{l}\mathrm{M}=14(29.7 \%) \\
\mathrm{F}=4(8.5 \%) \\
\mathrm{T}=18(38.2 \%)\end{array}$ & $\begin{array}{l}\mathrm{M}=0 \\
\mathrm{~F}=1(16.7 \%) \\
\mathrm{T}=1(16.7 \%)\end{array}$ & $\begin{array}{l}\mathrm{M}=0 \\
\mathrm{~F}=0 \\
\mathrm{~T}=0\end{array}$ & $\begin{array}{l}\mathrm{M}=0 \\
\mathrm{~F}=1(100 \%) \\
\mathrm{T}=1(100 \%)\end{array}$ & $\begin{array}{l}\mathrm{M}=0 \\
\mathrm{~F}=0 \\
\mathrm{~T}=0\end{array}$ & $\begin{array}{l}\mathrm{M}=4(20 \%) \\
\mathrm{F}=2(10 \%) \\
\mathrm{T}=6(30 \%)\end{array}$ \\
\hline $51-60$ & $\begin{array}{l}\mathrm{M}=4(16 \%) \\
\mathrm{F}=4(16 \%) \\
\mathrm{T}=8(32 \%)\end{array}$ & $\begin{array}{l}\mathrm{M}=8(17.02 \%) \\
\mathrm{F}=1(2.12 \%) \\
\mathrm{T}=9(19.14 \%)\end{array}$ & $\begin{array}{l}\mathrm{M}=1(16.7 \%) \\
\mathrm{F}=0 \\
\mathrm{~T}=1(16.7 \%)\end{array}$ & $\begin{array}{l}\mathrm{M}=1(50 \%) \\
\mathrm{F}=1(50 \%) \\
\mathrm{T}=2(100 \%)\end{array}$ & $\begin{array}{l}M=0 \\
F=0 \\
T=0\end{array}$ & $\begin{array}{l}M=0 \\
F=0 \\
T=0\end{array}$ & $\begin{array}{l}\mathrm{M}=4(20 \%) \\
\mathrm{F}=2(10 \%) \\
\mathrm{T}=6(30 \%)\end{array}$ \\
\hline $61-70$ & $\begin{array}{l}\mathrm{M}=0 \\
\mathrm{~F}=0 \\
\mathrm{~T}=0\end{array}$ & $\begin{array}{l}\mathrm{M}=3(6.38 \%) \\
\mathrm{F}=0 \\
\mathrm{~T}=3(6.38 \%)\end{array}$ & $\begin{array}{l}\mathrm{M}=0 \\
\mathrm{~F}=0 \\
\mathrm{~T}=0\end{array}$ & $\begin{array}{l}\mathrm{M}=0 \\
\mathrm{~F}=0 \\
\mathrm{~T}=0\end{array}$ & $\begin{array}{l}\mathrm{M}=0 \\
\mathrm{~F}=0 \\
\mathrm{~T}=0\end{array}$ & $\begin{array}{l}\mathrm{M}=0 \\
\mathrm{~F}=0 \\
\mathrm{~T}=0\end{array}$ & $\begin{array}{l}\mathrm{M}=3(15 \%) \\
\mathrm{F}=0 \\
\mathrm{~T}=3(15 \%)\end{array}$ \\
\hline $71-80$ & $\begin{array}{l}\mathrm{M}=0 \\
\mathrm{~F}=0 \\
\mathrm{~T}=0\end{array}$ & $\begin{array}{l}\mathrm{M}=2(4.25 \%) \\
\mathrm{F}=0 \\
\mathrm{~T}=2(4.25 \%)\end{array}$ & $\begin{array}{l}\mathrm{M}=0 \\
\mathrm{~F}=0 \\
\mathrm{~T}=0\end{array}$ & $\begin{array}{l}\mathrm{M}=0 \\
\mathrm{~F}=0 \\
\mathrm{~T}=0 \quad \mathrm{~S}\end{array}$ & $\begin{array}{l}\mathrm{M}=0 \\
\mathrm{~F}=0 \\
\mathrm{mpt} \underline{\mathrm{ms}}\end{array}$ & $\begin{array}{l}\mathrm{M}=0 \\
\mathrm{~F}=0\end{array}$ & $\begin{array}{l}\mathrm{M}=0 \\
\mathrm{~F}=0 \\
\mathrm{f}_{\mathrm{T}} \text { cases }\end{array}$ \\
\hline $\begin{array}{l}\text { Total } \\
(102)\end{array}$ & $\mathrm{n}=25$ & $\mathrm{n}=47$ & $\mathrm{n}=6$ & $\begin{array}{l}\text { Recaurrent } \\
\text { Patch of } d\end{array}$ & $\begin{array}{l}\text { loer } 1 \\
\text { coloration }\end{array}$ & $\mathrm{n}=1$ & $\begin{array}{l}3 \% \mathscr{2 0}) \\
.25 \%)\end{array}$ \\
\hline $\begin{array}{l}\text { Mean } \\
\text { age }\end{array}$ & 45.2 & 47.5 & 38.3 & $\begin{array}{l}55 \\
\text { Excessive } \\
\text { Itehing in }\end{array}$ & alivation & 38 & $\begin{array}{l}.4(2 \%) \\
.12 \%)\end{array}$ \\
\hline \multicolumn{4}{|c|}{$\begin{array}{l}\text { Table } 2 \\
\text { Symptoms in } 47 \text { case of Leukoplakia }\end{array}$} & \multicolumn{4}{|c|}{$\begin{array}{lc}\text { Burning in mouth } & 1(2.12 \%) \\
\text { Table } 5 & 39(82.9 \%) \\
\text { No symptoms } & \mathrm{N}=47 \\
\text { Site of involvement of mouth in } 20 \text { cases, clinically } \\
\text { suspected to be of cancer }\end{array}$} \\
\hline
\end{tabular}

\begin{tabular}{lc}
\hline \multicolumn{1}{c}{ Location } & No of cases \\
\hline Cheek & $7(35 \%)$ \\
Tongue & $5(25 \%)$ \\
Alveolar margin & $3(15 \%)$ \\
Tonsil & $2(10 \%)$ \\
Base of tongue and tonsil & $1(5 \%)$ \\
Alveolar margin and cheek & $1(5 \%)$ \\
Lip & $1(5 \%)$ \\
\hline
\end{tabular}


A.Singh, Role of exfoliative cytology in oral lesions: with special reference to rule out malignancy

Table 3

Cytological observation in Leukoplakia

Table 4

Cytological observation in 6 cases of submucous fibrosis

Table 6

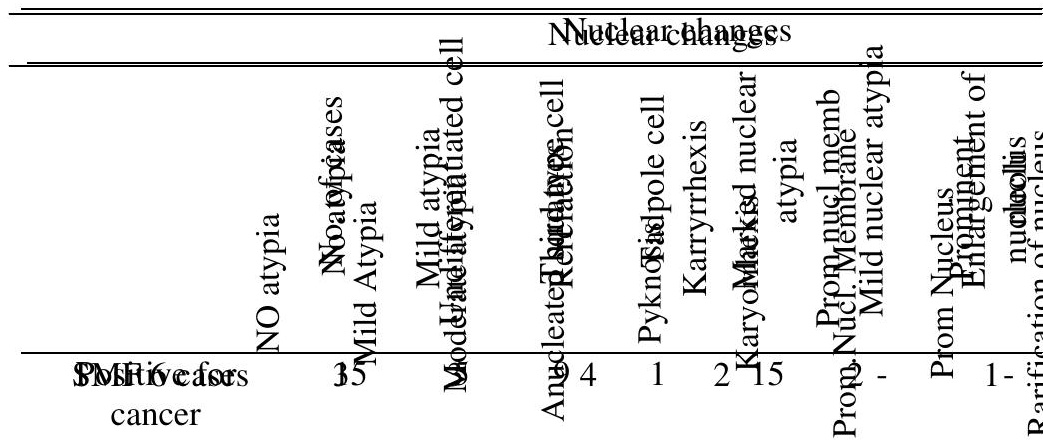

Cytological findings in 20 cases clinically suspected to be thosericitidgancer

Negative for

Percerfanger

$-\quad 25$

- 33233

$\begin{array}{lllllllll}66 & 23 & 11 & 53 & 51 & 25 & 11 & 6\end{array}$


Fig-1

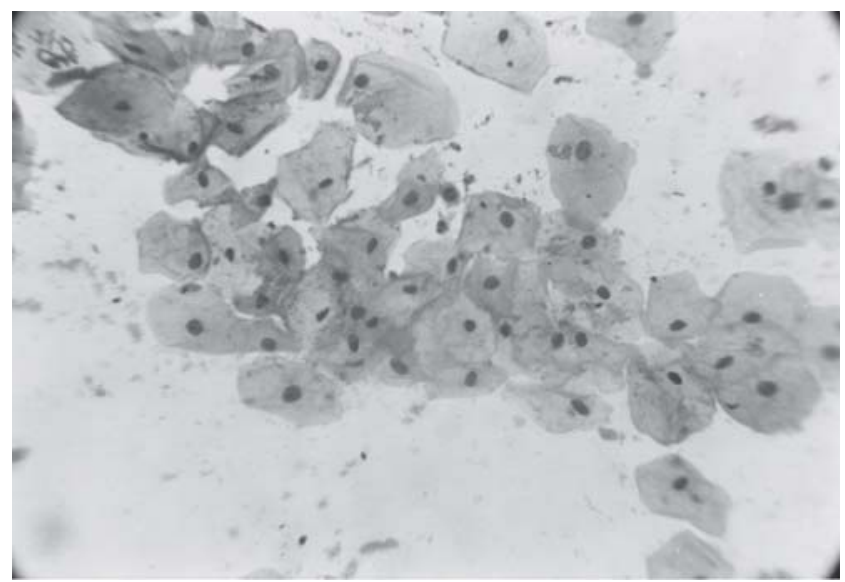

Normal Buccal Smear (Pap stain, x 400)

Fig-2

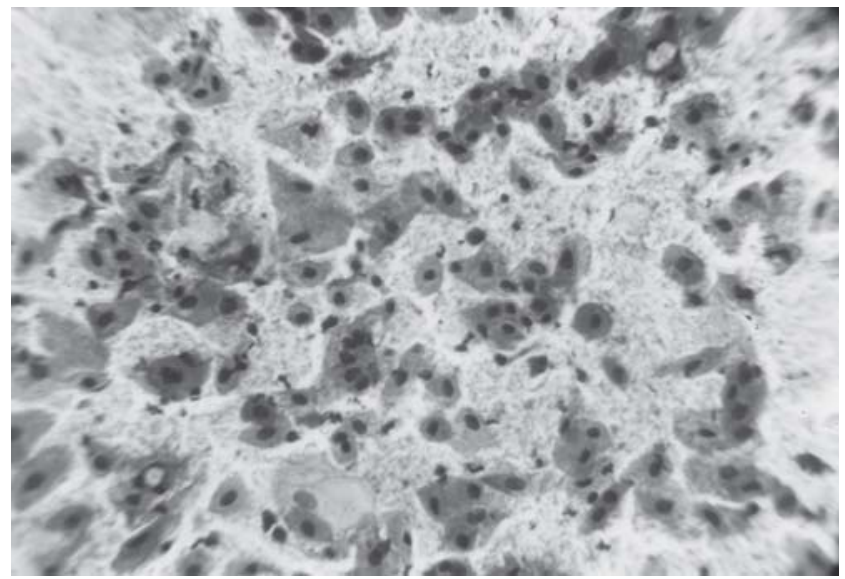

Mild Dysplasia (Pap stain, x 400)

Fig-3

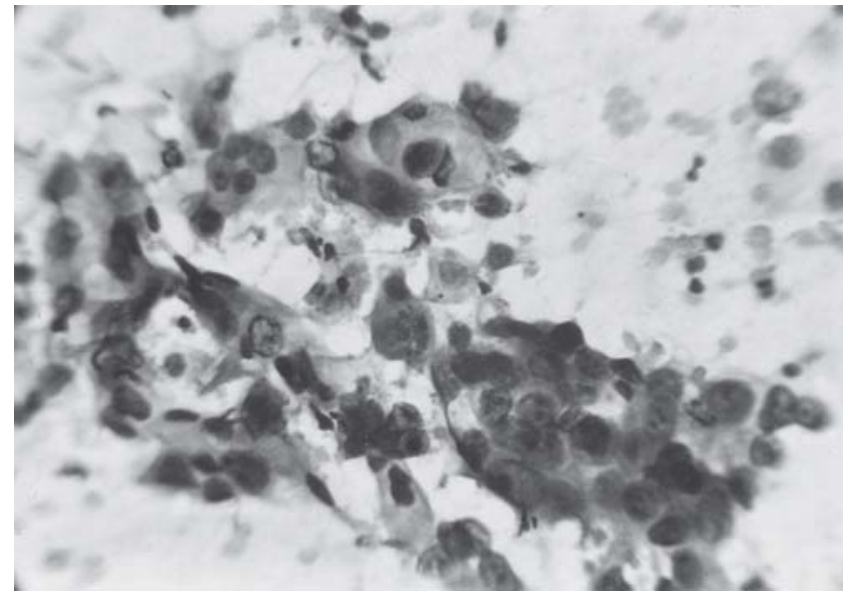

Moderate Dysplasia (Pap stain, x 400)
Fig-4

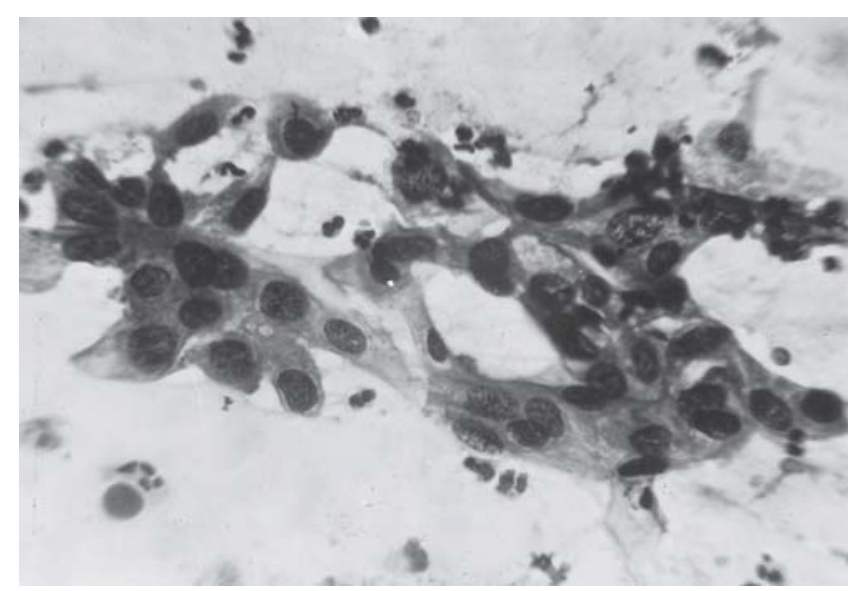

Severe Dysplasia (Pap stain, $\mathrm{x}$ 400)

Fig-5

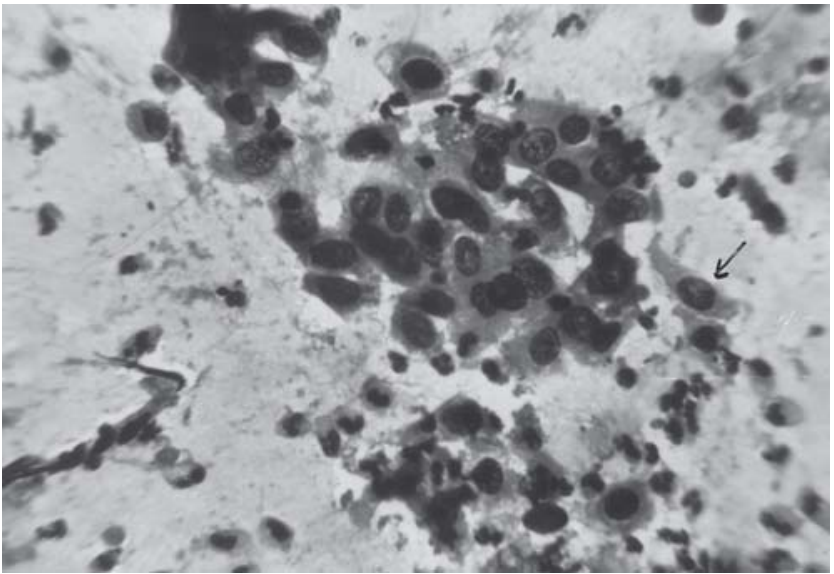

Squamous cell carcinoma (Pap stain, $x$ 400) 
A.Singh, Role of exfoliative cytology in oral lesions: with special reference to rule out malignancy

Two cases of mucosal hyperemia (erythema) were included in the present study. One case was male patient who gave history of heavy smoking. He had erythematous patches on the palate. The other case was female having no history of tobacco chewing.

Smears from these lesions revealed increased number of superficial cells and fair number of polymorphonuclear cells.

One female patient having chronic traumatic ulcer on her upper lip was also studied. Smears revealed mild degree of dyskaryosis in epithelial cells.

One male patient who had granular buccal mucosa was also included in the present study, smears prepared from mucosal surface did not reveal any significant abnormality.

In present study we found twenty cases of the cancer with maximum age incidence was 41-60 years (mean age 46 years) and $70 \%$ were male. In our study we also found all $100 \%$ cases with positive history of tobacco chewing or smoking. Cheek and tongue were the common sites of oral cancer with incidence of $60 \%$.(Table No.5)

The smear revealed inflammatory cells in $100 \%$, malignant cells in $75 \%$ cases either in groups or in singles. The third type of cells (cells having stand and clumps of nuclear chromatin, unevenly deposited at nuclear borders, irregular but well defined cytoplasmic borders and increased nuclear cytoplasmic ratio) were observed in $60 \%$ cases. The undifferentiated cells (cells in whom cellular borders are absent, nuclei are hyperchromatic, irregular in size and shape, chromatin arrangement in abnormal and nuclear borders are very sharp) were observed in $37 \%$ cases. Tadpole cells were least observed only in 5\% cases. (Table No.6)

Out of 20 clinically cancer suspected individuals, $75 \%$ were positive for cancer, $10 \%$ were suspicious for cancer and remaining $15 \%$ were given as negative for cancer.

\section{Discussion}

In our study the maximum age incidence of Leukoplakia was $31-40$ years observed in $61.7 \%$ cases. Tieche (1965) observed 80-90\% cases were above 40 years. ${ }^{11}$ Majority cases are $85 \%$ were male in present study. Similar observation made by Shafer and Waldron (1961) in 321 cases $70 \%$ were males. ${ }^{11,12}$ Buccal mucosa and alveolar mucosa were most common site of involvement of Leukoplakia by Tieche $(1965)^{11}$ similar observation $87.2 \%$ were obtained in present study also.

On microscopy, $74 \%$ of cases of Leukoplakia revealed predominant acidophilic character of cytoplasm in exfoliated cells and $51 \%$ of cases showed pyknotic nuclei, which is similar to observation by Wahi and Gupta (1954) approximately $75 \%$ of exfoliated superficial cells. ${ }^{13}$

Anucleated squames were another significant finding in present study it was $53.2 \%$, while Montgomery and Von Hamm(1951A) were so impressed with the findings of Anucleated squames that they thought it to be almost diagnostic of the leukoplakic lesions. ${ }^{14}$

In case of advanced Leukoplakia, varying degree of nuclear atypia of exfoliated cells in smear were observed. ${ }^{15,16}$ In the present study $11 \%$ cases of leukoplakia, revealed moderate degree of nuclear atypia.

In our study $50 \%$ submucous fibrosis were in age group of 31-40 years and $66.7 \%$ were female while in previous studies this was similar. Sirsat and Khanolkar (1954) in their study of 40 cases reported $18(45 \%)$ female and 22(55\%) male ${ }^{17}$ and Joshi et al (1953) cited by Sirsat and Khanolkar (1957), out of 41 cases 19 $(46.3 \%)$ were male and $22(53.7 \%)$ were females. ${ }^{17}$ 
An interesting finding in the smears from these areas was finding of rarified nuclei in $66 \%$ of cases. Wahi and Kehar (1955) ${ }^{16}$ have reported $68-82 \%$ of rarified nuclei in cyanophilic cells. Peters and Rysinghani (1956) also have similar observation. They considers it, significant finding as far as the cytological diagnosis of submucous fibrosis was concerned. ${ }^{15}$

Use of exfoliative cytology and cytoanalysis is a useful early diagnostic method for epithelial atypia and for oral lesion. ${ }^{18}$

There were 20 cases in this series, which were suspected to be of cancer on clinical examination. $70 \%$ patient were male and $60 \%$ in the age group of 41-60 years, with mean age of 46 years. Tieche (1965) reported average age incidence was 55 years and 80$85 \%$ were male. ${ }^{11}$ That may be because of excessive tobacco chewing and smoking in India.

In present study Third type cells were the most commonly observed malignant cells and present $60 \%$ of cases. The undifferentiated cells were comparatively less frequently observed $33 \%$. Tadpole cells were the least commonly encountered cells and seen only in one case.

King (1962) found fiber cells and tadpole cells only in 2 cases of his series. "Third type" differentiated cells were commonly seen. ${ }^{19}$ Cawson (1960) also found tadpole cell less common in smears of oral carcinoma (only in 1 case). ${ }^{20}$

Abnormally large nucleoli were seen in $66 \%$ of smears from patient suffering from oral carcinoma in our study. Montgomery found prominent nucleoli from $86 \%$ of such smears. ${ }^{[21]}$ Prominent nuclei were considered to be a common observation in smears from cases of carcinoma of mouth by many workers. ${ }^{9,10,20,22}$

\section{Conclusion}

Cellular appearance of benign oral lesion did not show appreciable or consistent differences from each other to permit diagnosis of lesions by cytological examination alone. Cytology is reliable as a diagnostic tool so far as diagnosis of presence or absence of malignancy in a lesion is concerned with high accuracy rate in diagnosing oral cancer.

The smear technique is not intended to replace tissue biopsy, but it is a valuable supplement to biopsy. Indications for its use include oral mucosal lesions, and follow up for patient with a history of either a premalignant or malignant lesion.

The oral cytologic technique is easy to do and can provide the help surgeon / physician, in cases where he/she might hesitate to perform an invasive procedure, like a biopsy, or desire more information regarding a lesion before referring the patient.

\section{Acknowledgement}

I wish to express thank and gratitude to Professor Bharat Jain, Head of Department Pathology for giving opportunity to do study on this topic, and making valuable comments and suggestions. I would also like to thanks Professor Rajesh Gaur for guiding my present study work.

\section{References}

1. American Cancer Society: Cancer Facts and Figures 2005. Atlanta, Ga: American Cancer Society, 2005. Also available online. Last accessed May 20, 2005.

2. Papanicolaou G.N. (1960): Classification of cytologic diagnosis. Chapter 5 in oral exfoliative cytology, Veterans Administration Co-operation Study (Sandler, 1962).

3. Nils G Stromby. Experience with buccal smears in the general cytopathology laboratory. Cancer 1999: 23: 23-6. 
A.Singh, Role of exfoliative cytology in oral lesions: with special reference to rule out malignancy

4. Anderson, WAD. Pathology $10^{\text {th }}$ Ed.St. Louis, M.O. the C.V. Mosby Company,1996:405-6.

5. Sandler HC. The detection of early cancer of the mouth by exfoliative cytology. Acta Cytol 1961; 5: 191 -4.

6. Sandler HC. : Oral exfoliative cytology. Veterans Administration Co-operative study. Supdt. Of DOC U.S. Govt. Printing Office, Washington, D.C;1962.

7. Sandler HC. Veterans Administration Co-operative study of oral exfoliative cytology. Acta Cytol 1963; 7: 180-2.

8. Sandler HC. Reliability of oral exfoliative cytology for detection of oral cancer. J Amer Dent Ass 1964; 68: 1.

9. Peters H. Cytologic smears from the mouth: Cellular changes in disease and after radiation. Am J Clin Path 1958; 29: 219.

10. Silverman S, Becks H, Farber SM. The diagnostic value of intra-oral cytology. J Dent Res 1977; 37: 195-205.

11. Tiecke RW. Oral Pathology, New York. The Blakiston Division, McGraw Hill Book Co., 1965: 623-5.

12. Shafer WG, Hine MK, Levy BM. A text book of oral pathology, $2^{\text {nd }}$ Ed. Philadelphia, Pa., W.B. Saunders Company.1963:465-7.

13. Wahi PN and Gupta K. Exfoliative cytology in diagnosis of carcinoma of oral cavity. J Ind Med Ass 1954; 23: 425.
14. Montgomery PW, Von Haam E. A study of the exfoliative cytology of oral leukoplakia. J Dent Res 1951; 30: 260-4.

15. Peters H, Rysinghani K. The cytologic interpretation of mouth smears. J Ind Med Ass 1956; 27: 231-6.

16. Wahi PN, Kehar U. Morphological and cytochemical studies of precancerous lesions of oral cavity. Acta Cytol 1966; 10: 173-8.

17. Sirsat SM, Khanolkar VR. Histochemical and electron microscopic study of submucous fibrosis of the palate. Ind J Path \& Bact 1957; 73: 439-42.

18. Ahmed HG, Idris AM, Ibrahim SO. Study of oral epithelial atypia among Sudanese tobacco users by exfoliative cytology. Anticancer Res 2003; 23: 1943-9.

19. King $\mathrm{OH}$. The cytology of common and uncommon oral malignancies. Acta Cytol 1962; 6: 348-54.

20. Cawson RA. The cytological smear in diagnosis of oral cancer. Brit Dent J 1960; 108: 294.

21. Montgomery PW. A study of exfoliative cytology of normal human oral mucosa. J Dent Res 1951; 30: 12-8.

22. Sandler HC, Stahl SS. Exfoliative cytology; a diagnostic aid in the detection of oral neoplasms. J oral Surg 1958; 16: 414 . 